\title{
Purification and Biochemical Characterization of a Protease Inhibitor II Family from Jalapeño Pepper (Capsicum annuum L.)
}

\author{
Juan Pablo Carrillo-Montes' ${ }^{1}$, Roberto Arreguín-Espinosa1, José Luis Muñoz-Sánchez², \\ Manuel Soriano-García ${ }^{1}$ \\ ${ }^{1}$ Departamento de Química de Biomacromoléculas, Instituto de Química, Universidad Nacional Autónoma de \\ México, México DF, México \\ ${ }^{2}$ Departamento de Bioquímica, Escuela Nacional de Ciencias Biológicas del Instituto Politécnico Nacional, \\ México DF, México \\ Email: soriano@unam.mx
}

Received 5 April 2014; revised 28 May 2014; accepted 16 June 2014

Copyright (C) 2014 by authors and Scientific Research Publishing Inc.

This work is licensed under the Creative Commons Attribution International License (CC BY).

http://creativecommons.org/licenses/by/4.0/

(c) (i) Open Access

\section{Abstract}

Capsicum annuum L. was initially domesticated in Mexico and northern Central America, and represented an ancient Neotropical plant food complex. The purpose of this paper is to report the isolation and purification of a novo-member of a protease inhibitor from jalapeño pepper (Capsicum annuum L.) (PIJP). The molecular weight of PIJP inhibitor is $5.95 \mathrm{kDa}$ with 56 amino acids and 6 Cys residues with high inhibitory activity to trypsin with a $K_{i}$ value of $95 \mathrm{nM}$. This inhibitor according to the alignment with homologous from NCBI and Pfam databases is a member of proteinase inhibitors II. It is worthwhile to mention a major compositional difference between the proteinase inhibitor II families which have 8 Cys residues. PIJP is the first purified proteinase inhibitor, member of this family with only 6 Cys residues.

\section{Keywords}

Protease Inhibitory Activity, Protease Inhibitor, Protein Purification, Jalapeño Pepper, Capsicum annuum L.

\section{Introduction}

The genus Capsicum (vegetable pepper) was initially domesticated in Mexico, northern Central America and the

How to cite this paper: Carrillo-Montes, J.P., et al. (2014) Purification and Biochemical Characterization of a Protease Inhibitor II Family from Jalapeño Pepper (Capsicum annuum L.). Advances in Bioscience and Biotechnology, 5, 661-668. 
Andean region of South America. Five species, among 38 in the genus [1], were independently domesticated and had been cultivated primarily for use as a spice and vegetable for thousands of years [2]. Capsicum varieties have diverse uses as food products like fresh or processed vegetables, spices or even as medicines and pest control, which make this crop of immense cultural and economic importance [3].

In Mexico, the pepper fruits (Capsicum annuum L.) are important vegetables usually consumed both as a food and as a spice. The chili pepper is a major commercial crop in Mexico, accounting for over 1,990,000 tons of production in 2009. Of these, 618,684 tons were Jalapeño peppers and 216,717 tons were Serrano peppers [4]. These two pepper species are most commonly consumed in a raw state (e.g., green salads, sauces), both in Mexico and other countries. Capsicum annuum L., popularly known in Mexico as "chile", has a very large number of varieties, and only a few have been studied in detail. Although C. annuum L. is originally from the American Continent, its use has spread to many countries all around the world. Some applications are related to their varied flavour while others are related to their colour [3] [5].

The jalapeño pepper, also known as the Mexican pepper, has been broadly used since Pre-hispanic time as food, antimicrobial and other medical applications [6].

The protease inhibitors (PIs) are storage proteins that perform essential roles in plant survival, acting as molecular reserves that are important for plant growth and maintenance, as well as being involved in defense mechanisms [7]-[9]. PIs are found in both germinative tissue, such as seeds and kernels, and vegetative tissue, as tubercles and leaves [10] [11]. PIs share a common trait, the ability to form complexes with proteinases, causing the enzymes to lose their biological activity [12].

Based on the primary and spatial structure characteristics, including the number and position of the disulfide bonds and the active sites, the plant protease inhibitors are classified in families and clans (A clan of peptidase inhibitors contains all the inhibitors from a single evolutionary origin of inhibitors) [13]-[15].

The inhibitors of family I20 (proteinase II o potato II) are produced as part of a response by plants of the Solanaceae family by the attack from pathogens. Tamhane et al. [16] demonstrated that tomato proteinase II will stop larval growth and development in Helicoverpa armigera.

These plants PIs have been recently identified in several medical applications as anticarcinogenic, chemoprevention agents of human prostate cancer, anti-inflammatory, radioprotector, and bioprotector of other bioactive compounds [17]-[20].

The purpose of this study is to report the isolation and purification of a protease inhibitor from jalapeño pepper (Capsicum annuum L.) and the determination of its inhibitory capacity against trypsin.

\section{Materials and Methods}

\subsection{Materials}

Jalapeño pepper seeds (Capsicum annuum L.) of Don Benito variety, free of insecticide were kindly provided by M. in Sc. MoisesMeráz, from the Instituto Nacional de Investigaciones Forestales y Agropecuarias (INIFAP Tamaulipas), México. Trypsin 10000 U BAEE, N-( $\alpha$-Benzoyl-L-Arginine Ethyl Ester (BAEE), Sephadex QAE, Sephadex G50 media were purchased from Sigma-Aldrich, Toluca, México. Thermo Scientific Pierce BCA Protein Assay Kit.

\subsection{Miscellaneous Methods}

Protein contents were estimated by Bicinconinic acid (BCA) with bovine serum albumin as a standard (1 $\mathrm{mg} / \mathrm{mL}$ ), by a microplate procedure [21].

The homogeneity was evaluated by performing isoelectric focusing using Phast System apparatus from Pharmacia Biotech. Phast Gel IEF 3 - 9 was used together with a (Pharmacia) broad range PI calibration kit containing proteins with various isoelectric points.

\subsection{Trypsin Activity and Inhibitory Activity Assay}

Schwert and Takenaka [22] found that the absorption of BAEE is much weaker at $253 \mathrm{~nm}$ than that of $\mathrm{N}-(\alpha)$ benzoyl-L-arginine, hence the hydrolysis of the ester can be followed spectrophotometrically. With a volume of $1.06 \mathrm{~mL}$ an optical density change of $1.085 / \mathrm{min}$ corresponds to the conversion of $1 \mu \mathrm{mol}$ of substrate/min.

The trypsin activity was measured using a $1 \mathrm{~mL}$ of $1 \mathrm{mM}$ BAEE in Tris buffer $\mathrm{pH} 8$ with $0.02 \mathrm{M} \mathrm{CaCl}_{2}$, add- 
ing $10 \mu \mathrm{L}$ of trypsin $(0.235 \mathrm{mg} / \mathrm{mL})$ and $50 \mu \mathrm{L}$ of Tris buffer $\mathrm{pH} 8$ with $0.02 \mathrm{M} \mathrm{CaCl}_{2}$.

The trypsin activity is defined as the amount of substrate reacting ( $\mu \mathrm{moles} / \mathrm{min}$ ) per $\mathrm{mg}$ protein and calculated by using the Equation (1).

$$
U A=\Delta A_{254} /(1.085 \mathrm{~min}(\mathrm{mg} \text { enzyme }))
$$

A control mixture was prepared by using $50 \mu \mathrm{L}$ of a $20 \mathrm{mM}$ Tris buffer $\mathrm{pH} 8$ instead of the $50 \mu \mathrm{L}$ of sample. The inhibitory activity was made using trypsin, adding $50 \mu \mathrm{L}$ of extract instead of a buffer. The trypsin inhibitory activity is defined as unit's trypsin activity inhibited per mg protein (jalapeño seeds extract) and calculated by using the Equation (2).

$$
U A I=\left(U A_{\text {ref }}-U A_{\text {extract }}\right) /(m g \text { protein })
$$

The inhibition constant $K_{i}$ was calculated by using the Cha's equation [23] for a tight-binding inhibitor (Equation (3)).

$$
K_{i}=\left(I_{50}-E_{t} / 2\right) /\left(1+[S] / K_{m}\right)
$$

where $E_{t}$ is the total enzyme concentration, [S] is the total substrate concentration, $I_{50}$ is the inhibitor concentration at which the velocity of the enzyme reaction was $50 \%$ of the uninhibited reaction, $K_{m}$ is the Michaelis constant and $K_{i}$ is the inhibition constant or the dissociation constant of the enzyme-inhibitor complex. All measure was validated by t-student assay, results representative of three independent experiment; deviations dependent on seed quality ( $\mathrm{p}>95 \%)$.

\subsection{Sequence Determination}

For mass spectrometry measurements, the purified PIJP was dissolved in 20\% acetonitrile/0.1\% TFA in water. Protein solution (100 pmol) was diluted 200 -fold in a saturated solution of $\alpha$-cyano-4-hydroxycinnamic acid, in 50\% ethanol [24]. Enzymatic digestion of PIJP was carried out using trypsin and chymotrypsin (modified sequencing grade). The enzyme was dissolved in $20 \mu \mathrm{L}$ of $1 \mathrm{mM} \mathrm{HCl}$ to a final concentration of $1.25 \mu \mathrm{g} / \mu \mathrm{L} ; 50$ $\mu \mathrm{L}$ of PIJP protein solution (1000 pmol) was reacted with $48 \mu \mathrm{L}$ of $25 \mathrm{mM} \mathrm{NH}_{4} \mathrm{HCO}_{3}$ at $\mathrm{pH} 8.4$ and $2 \mu \mathrm{L}$ trypsin solution. The mixture was agitated and incubated at room temperature for $3 \mathrm{~h}$, and the solution was diluted 200-fold in a matrix solution. The final peptide solutions were deposited on the sample slide of a Kratos (Manchester, England) Kompact. MALDI IV-TOF spectrometer using the Autodrop System (Microdop, Norderstedt, Germany). The mass spectrometer was equipped with $337 \mathrm{~nm}$ pulsed $\mathrm{N}_{2}$ laser for MALDI ionization, and a curved-field reflectron for obtaining PSD spectra. The instrument was operated in the positive ion mode with 20 $\mathrm{kV}$ extraction voltages. The N-terminal and fragment sequences were determined by automated Edman degradation [25] on a gas-phase protein sequencer (LF 3000, Beckman Instruments, Irvine, CA) equipped with an online high performance liquid chromatography system (Beckman System Gold, Beckman Instruments, Irvine, CA). HPLC equipment included a diode array detector with settings at 268 and $293 \mathrm{~nm}$ for signal and reference, respectively. The HPLC column used was a Beckman Spherogel Micro PTH (2 mm - 150 mm) column; standard Beckman sequencing reagents were used for analysis.

\subsection{Spectroscopy}

Far-UV CD spectra of $0.1 \mathrm{mg} / \mathrm{mL}$ PIJP in Tris buffer $\mathrm{pH} 8$ protein solutions were recorded at $25^{\circ} \mathrm{C}$ in the spectral range from 190 to $260 \mathrm{~nm}$ on a Jasco J-715 spectropolarimeter (Jasco Spectroscopic Co., Ltd., Hachioji City, Japan) equipped with a Jasco PTC-423S temperature control unit using a quartz cuvette with an optical path of $0.1 \mathrm{~cm}$. The spectral resolution was $1 \mathrm{~nm}$, the scan speed was $50 \mathrm{~nm} / \mathrm{min}$, and the response time was $4 \mathrm{~s}$ with a bandwidth of $1 \mathrm{~nm}$. The measurements were made for three replicates and three scans were accumulated and averaged. The spectra were corrected for a protein-free sample.

\subsection{Extraction and Purification of Protease Inhibitor from Jalapeño Pepper (PIJP)}

$0.2 \mathrm{Kg}$ of finely ground jalapeño pepper seeds were subjected to extraction with $1 \mathrm{~L}$ of $0.01 \mathrm{M}$ phosphate buffer containing $0.1 \mathrm{M} \mathrm{NaCl}$ ( $\mathrm{pH} 7.4$ ) at room temperature for $3 \mathrm{~h}$. The solution phase was separated by centrifugation at $4000 \mathrm{~g}$ for $30 \mathrm{~min}$ and the extraction was repeated with $1 \mathrm{~L}$ of the same buffer at $4^{\circ} \mathrm{C}$ for $16 \mathrm{~h}$ and combined. 
The solution phases were combined and acidified to $\mathrm{pH} 4.6$ with $\mathrm{HCl}$ concentrated, heat-treated at $85^{\circ} \mathrm{C}$ for 15 $\mathrm{min}$, cooled to room temperature and the precipitate formed was centrifuged at $4000 \mathrm{~g}$ for $15 \mathrm{~min}$. The supernatant was subjected to precipitation with $80 \%\left(\mathrm{NH}_{4}\right)_{2} \mathrm{SO}_{4}$ then centrifuged at $20000 \mathrm{~g}$ for $30 \mathrm{~min}$ at $4^{\circ} \mathrm{C}$, the precipitated was dialyzed against distilled water at refrigerated temperature $4{ }^{\circ} \mathrm{C}$ then lyophilised.

This material was applied on a QAE-25-120 Sephadex $(1.7 \times 50 \mathrm{~cm})$ pre-equilibrated column with Tris 0.05 $\mathrm{M} \mathrm{pH}$ 8. After eluting the unbound proteins, a $\mathrm{NaCl}$ with stepwise gradient from $0,0.05,0.1,0.2$ and $1 \mathrm{M}$ of $\mathrm{NaCl}$ in the same buffer was applied at a flow rate of $0.3 \mathrm{~mL} / \mathrm{min}$, every $100 \mathrm{~mL}$ each step. The fractions with the most trypsin inhibition were pooled, desalted and lyophilised. This material was re-purified on a Sephadex G-50 $(2 \times 66 \mathrm{~cm})$ column and the fraction inhibiting trypsin was pooled and lyophilised. The sample homogeneity was evaluated with MALDI-TOF-MS and isoelectric focusing chromatography.

Homology sequences between PIJP inhibitor and other known related proteins were searched using the Basic Local Alignment Search Tool (BLAST) algorithm, Protein data bank (PDB) and Pfam databases. Multiple alignments were carried out using Multiple Sequence Comparison by Log-Expectation (MUSCLE) on EMBL-EBI web service [26].

\section{Results and Discussion}

\subsection{Purification of Protease Inhibitor from Jalapeño Pepper}

Purification of PIJP was achieved by monitoring the trypsin inhibitory activity during the purification protocol. Table 1 summarizes the purification scheme that rendered a 302 fold increase in the final purification. The yield (1.49\%) was calculated with the inhibitory activity and the protein content. The jalapeño pepper seeds are a rich source of proteins with approximately $13 \%$ of protein. From $0.2 \mathrm{Kg}$ of seeds only $1.21 \mathrm{mg}$ of pure PIJP inhibitor was obtained.

Anion exchange chromatography of precipitated at $80 \%$ of $\left(\mathrm{NH}_{4}\right)_{2} \mathrm{SO}_{4}$ and dialyzed showed six fractions, the fraction at $5 \%$ of Tris buffer $\mathrm{pH} 8$, containing $\mathrm{NaCl} 1 \mathrm{M}$, at $170 \mathrm{ml}$ elution volume, showed 1658 UAI (Figure 1(a)). The last step of purification was molecular exclusion (Figure 1(b)), using Sephadex G-50 to desalt and to

Table 1. Steps summary and purification yields of PIJP inhibitor.

\begin{tabular}{ccccc}
\hline STEP & Protein $(\mathrm{mg})$ & Yield (\%) & UAI (UA inhibited/mg) & Purification \\
\hline Extraction & 24482 & 100 & 27.53 & 1 \\
Precipitation $\left(\mathrm{NH}_{4}\right)_{2} \mathrm{SO}_{4} 80 \%$ & 2388 & 95.56 & 269.7 & 9.8 \\
Sephadex QAE & 37.04 & 9.11 & 1658 & 60.2 \\
Sephadex G-50 gel filtration & 1.21 & 1.49 & 8315 & 302.0 \\
\hline
\end{tabular}

Results representative of three independent experiment; deviations dependent on seed quality (p > 95\%). The yield was calculated with the inhibitory activity and the protein content.

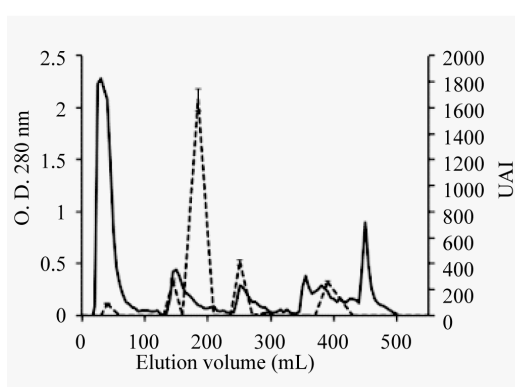

(a)

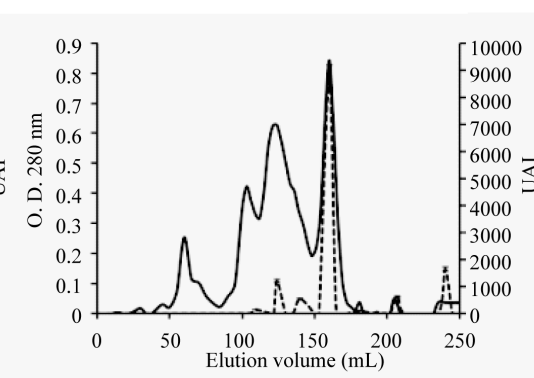

(b)

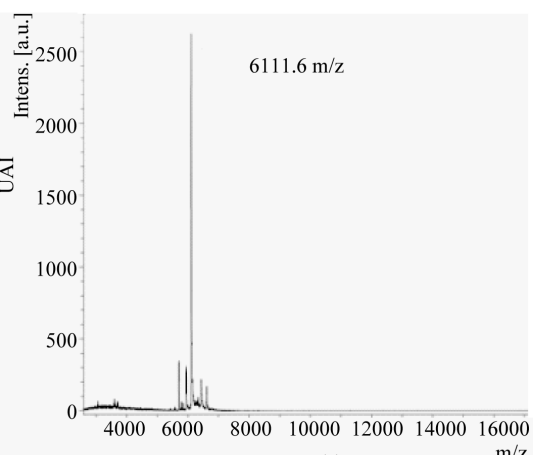

(c)

LAYMVCEGESRICTVCTHNCAAGKGENYRSADGTYICEGESPAGKGKLACPRLIRV

(d)

Figure 1. (a) Anion exchange chromatography (Sephadex QAE) of seed pepper extract, the dot line across the chromatogram indicates inhibitory activity (UAI); (b) Elution profile of fraction with major inhibitory activity eluted from Sephadex QAE onto Sephadex G-50, the dot line across the chromatogram indicates inhibitory activity (UAI); (c) MALDI/MS spectrum of the purified PIJP inhibitor; (d) Protease Inhibitor Jalapeño Pepper sequence, CID-MS technique. 
eliminate high weight molecular protein. The inhibitory activity increased almost five times (8315 UAI). Figure 1(c) shows the MALDI/MS spectrum of the purified PIJP inhibitor and theoretical molecular weight of PIJP was $5.954 \mathrm{kDa}$ using its amino acid composition on EMBL-EBI web services [26] and agrees with experimental molecular weight determined by molecular exclusion and also with the MALDI-TOF-MS. The experimental isoelectric point using Phast Gel 3 - 9 was 8, and the theoretical isoelectric point at 7.66 on EMBL-EBI web services [26], the difference between them are must be molecular conformation.

\subsection{Amino Acid Sequence of PIJP and Structural Similarities}

The homogeneity was evaluated with MALDI-TOF-MS (Figure 1(c)) and isoelectric focusing chromatography; PIJP sequence was determinate by CID-MS (Figure 1(d)). Considering nr database, almost 100 sequences were found; PIJP sequence is member of proteinase inhibitors II or potato II family. The similarity was especially high with a value greater than $60 \%$, in the case of the related proteinase inhibitor from genera Capsicum, Solanum, Nicotiana, all are members of the Solanaceae family. All members of proteinase inhibitors II have four disulphide bridge unlike with PIJP (Figure 1 and Figure 2), that has six Cys residues; and has only tree disulphide bridges, that were determined by mass spectrometry technique by reducing and alkylating all cysteine residues.

\subsection{PIJP Characteristics and Inhibitory Activity}

Secondary structure of PIJP is predominant random coil almost 90\%, it’s confirmed with secondary structural studies using circular dichroism and the Dicroweb software [27]. Some papers reported, proteinase inhibitor II contains a three-stranded $\beta$-sheet and four $\beta$-turns and four disulfide bridges stabilize the structure [28] [29]. The inhibitors from Solanceae family are part of the proteinase inhibitors II, with 6 - $21 \mathrm{kDa}$ and 8 Cys residues and have high inhibitory activity to trypsin.

The molecular weight of PIJP inhibitor is $5.95 \mathrm{kDa}$ with 56 amino acids and 6 Cys residues, forming three disulfide bridges, determined by mass spectrometry technique by reducing and alkylating all cysteine residues. These disulfide bridges are very important to maintain biological activity and secondary structure of proteinase inhibitors [30].

The calculated $I_{50}$ value of PIJP was $641 \mathrm{nM}$ (Figure 3(a)), using Cha's equation [23] for tight binding, the $K_{i}$ is $95 \mathrm{nM}$ (Figure 3(b)), has a lower affinity than PSI-1.1 $\left(K_{i} 0.48 \mathrm{nM}\right)$ and PSI-1.2 $(47 \mathrm{nM})$ in bell pepper (Capsicum annuum L.) [11] and higher affinity than PIs from Lycopersicon esculentum $\left(K_{i} 200 \mathrm{nM}\right)$ [14].

\section{Conclusions}

The molecular weight of PIJP inhibitor is $5.95 \mathrm{kDa}$ with 56 amino acids and 6 Cys residues forming threedisulphide bridge. Considering NR database, PIJP sequence is a member of proteinase inhibitors II or potato II family with $62 \%$ of identity. All members of proteinase inhibitors II have four-disulphide bridge in contradistinction to PIJP, which has six Cys residues.

PIJP has good inhibitory activity to trypsin with a $K_{i}$ value of $95 \mathrm{nM}$, and it has a bit less affinity than $K_{i} 0.48$ $\mathrm{nM}$ of PSI-1.1 and $K_{i} 47 \mathrm{nM}$ of PSI-1.2 from Capsicum annuum and higher than PIs from Lycopersicon esculentum $\left(K_{i} 200 \mathrm{nM}\right)$.

\section{Acknowledgements}

Special thanks to DGAPA-UNAM, Project PAPIIT IN200711 and J. P. Carrillo Montes thanks CONACyT

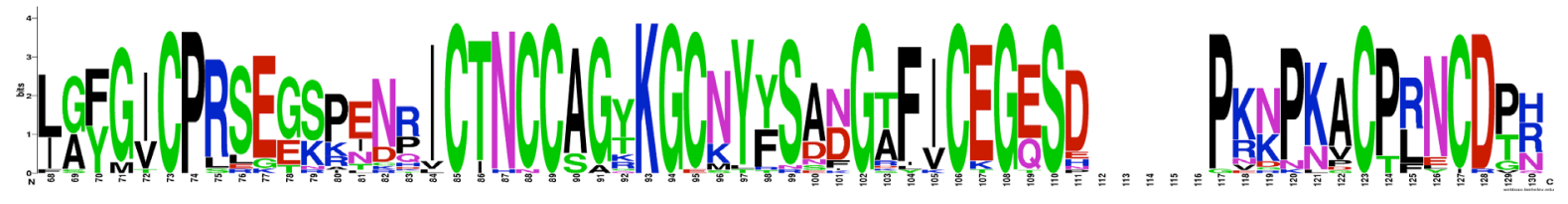

Figure 2. Graphical representation of PIJP sequence alignment using Multiple Sequence Comparison by Log-Expectation (MUSCLE) on EMBL-EBI web service [26], using WebLogo [31]. PIJP homology sequences were searched with BLAST using NR protein sequence and were exclude sequences that have been expressed on other organisms. 


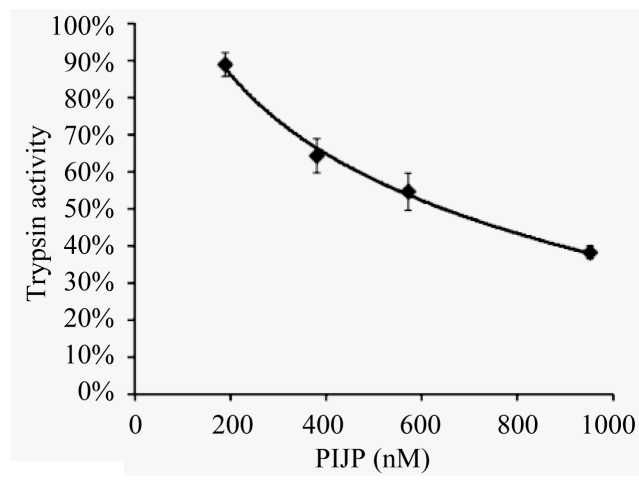

(a)

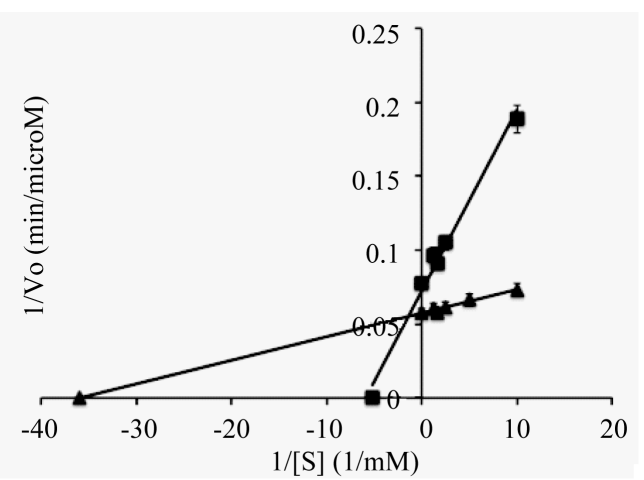

(b)

Figure 3. Effect of PIJP against trypsin activity. (a) An curve of trypsin inhibition by PIJP, enzyme activity was inhibited by increased amount of PIJP and inhibitory activity was monitored using BAEE as substrate. The $100 \%$ of activity refers to the absorbance without PIJP. $I_{50}$ was defined as the concentration of PIJP required for achieved 50\% inhibition for achieved 50\% inhibition of enzyme. Each mean represents 5 replicates ( $p>95 \%$ ); (b) Double-reciprocal plot of $V_{0}$ and [S], triangle represent trypsin activity without inhibitor and square represent inhibition of trypsin by PIJP.

for his fellowship (206846). M in Sc. Moises Meráz, from INIFAP Tamaulipas to provided jalapeño seeds, Don Benito variety.

\section{References}

[1] Germplasm Resources Information Network-(GRIN) (2013) United States Department of Agriculture, Agricultural Research Service, National Genetic Resources Program. http://www.ars-grin.gov/cgi-bin/nggs/html/genform.pl

[2] Paran, I., Ben-Chaim A., Kang, B.C. and Jahn, M. (2006) Capsicum. In: Kole, C., Ed., Genome Mapping and Molecular Breeding in Plants. Springer, Berlin, 209-226.

[3] Bosland, P. and Votava, E. (2000) Peppers: Vegetable and Spice Capsicums. Cambridge: CABI Publishing.

[4] SAGARPA. Servicio de InformaciónAgrolimentaria y Pesquera (2012) Un panorama del cultivo de chile. http://www.siap.gob.mx/images/stories/infogramas/100705-monografia-chile.pdf

[5] Montes, J.P.C., Cruz y Victoria, M.T., Sosa, I.A. and Pineda, T.S. (2010) Quality Assessment of Dehydrated Red Bell Pepper Using Tempering Drying Cycles. International Journal of Food Science \& Technology, 45, 1270-1276. http://dx.doi.org/10.1111/j.1365-2621.2010.02273.x

[6] Cichewicz, R.H. and Thorpe P.A. (1996) The Antimicrobial Properties of Chile Peppers (Capsicum species) and Their Uses in Mayan Medicine. Journal of Ethnopharmacology, 52, 61-70.

http://dx.doi.org/10.1016/0378-8741(96)01384-0

[7] Murdock, L.L. and Shade, R.E. (2002) Lectins and Protease Inhibitors as Plant Defenses against Insects. Journal of Agricultural and Food Chemistry, 50, 6605-6611. http://dx.doi.org/10.1021/jf020192c

[8] Mägert, H.J., Drögemüller, K. and Raghunath, M. (2005) Serine Proteinase Inhibitors in the Skin: Role in Homeostasis and Disease. Current Protein and Peptide Science, 6, 241-254. http://dx.doi.org/10.2174/1389203054065374

[9] Agrawal, A.A. (2011) Current Trends in the Evolutionary Ecology of Plant Defence. Functional Ecology, 25, 420-432. http://dx.doi.org/10.1111/j.1365-2435.2010.01796.x

[10] de Souza Cándido, E., Pinto, M.F.S., Pelegrini, P.B., Lima, T.B., Silva, O.N., Pogue, R., Grossi-de-Sa, M.F. and Franco, O.L. (2011) Plant Storage Proteins with Antimicrobial Activity: Novel Insights into Plant Defense Mechanisms. The FASEB Journal, 25, 3290-3305. http://dx.doi.org/10.1096/fj.11-184291

[11] Antcheva, N., Patthy, A., Athanasiadis, A., Tchorbanov, B., Zakhariev, S. and Pongor, S. (1996) Primary Structure and Specificity of a Serine Proteinase Inhibitor from Paprika (Capsicum annuum) Seeds. Biochimicaet Biophysica Acta, 1298, 95-101.

[12] Gomes M.T., Oliva M.L., Lopes M.T. and Salas C.E. (2011) Plant Proteinases and Inhibitors: An Overview of Biological Function and Pharmacological Activity. Current Protein and Peptide Science, 12, 417-436. http://dx.doi.org/10.2174/138920311796391089

[13] Mosolov, V. and Valueva, T. (2005) Proteinase Inhibitors and Their Function in plants: A Review. Applied Biochemistry and Microbiology, 41, 227-246. http://dx.doi.org/10.1007/s10438-005-0040-6 
[14] Christeller, J. and Laing, W. (2005) Plant Serine Proteinase Inhibitors. Protein and Peptide Letters, 12, 439-447. http://dx.doi.org/10.2174/0929866054395329

[15] Habib, H. and Fazili, K.M. (2007) Plant Protease Inhibitors: A Defense Strategy in Plants. Biotechnology and Molecular Biology Reviews, 2, 68-85.

[16] Tamhane, V.A., Chougule, N.P., Giri, A.P., Dixit, A.R., Sainani, M.N. and Gupta, V.S. (2005) In Vivo and in Vitro Effect of Capsicum annuum Proteinase Inhibitors on Helicoverpaarmigera Gut Proteinases. Biochimica et Biophysica Acta, 1722, 156-167.

[17] Ware, J.H., Wan, X.S., Rubin, H., Schechter, N.M. and Kennedy, A.R. (1997) Soybean Bowman-Birk Protease Inhibitor Is a Highly Effective Inhibitor of Human Mast Cell Chymase. Archives of Biochemistry and Biophysics, 344, 133138. http://dx.doi.org/10.1006/abbi.1997.0182

[18] Fernanda Troncoso, M., CerdáZolezzi, P., Hellman, U. and Wolfenstein-Todel, C. (2003) A Novel Trypsin Inhibitor from Peltophorumdubium Seeds, with Lectin-Like Properties, Triggers Rat Lymphoma Cell Apoptosis. Archives of Biochemistry and Biophysics, 411, 93-104. http://dx.doi.org/10.1016/S0003-9861(02)00726-9

[19] Birk, Y. (2003) Plant Protease Inhibitors: Significance in Nutrition, Plant Protection, Cancer Prevention and Genetic Engineering. Springer Verlag, Berlin.

[20] Clemente, A., Gee, J.M., Johnson, I.T., Mackenzie, D.A. and Domoney, C. (2005) Pea (Pisumsativum L.) Protease Inhibitors from the Bowman-Birk Class Influence the Growth of Human Colorectal Adenocarcinoma HT29 Cells in Vitro. Journal of Agricultural and Food Chemistry, 53, 8979-8986. http://dx.doi.org/10.1021/jf051528w

[21] Brown, R.E., Jarvis, K.L. and Hyland, K.J. (1989) Protein Measurement Using Bicinchoninic Acid: Elimination of Interfering Substances. Analytical Biochemistry, 180, 136-139. http://dx.doi.org/10.1016/0003-2697(89)90101-2

[22] Schwert, G.W. and Takenaka, Y. (1955) A Spectrophotometric Determination of Trypsin and Chymotrypsin. Biochimicaet Biophysica Acta, 16, 570-575. http://dx.doi.org/10.1016/0006-3002(55)90280-8

[23] Cha, S. (1975) Tight-Binding Inhibitors-I. Kinetic Behavior. Biochemical Pharmacology, 24, 2177-2185. http://dx.doi.org/10.1016/0006-2952(75)90050-7

[24] Cabra, V., Vázquez-Contreras, E., Moreno-Cárcamo, A. and Arreguin-Espinosa, R. (2008) The Effect of Sulfhydryl Groups and Disulphide Linkage in the Thermal Aggregation of Z19 Alpha-Zein. Biochimica et Biophysica Acta, 1784, 1028-1036.

[25] Edman, P. and Begg, G. (1967) A Protein Sequentator. European Journal of Biochemistry, 1, 80-91. http://dx.doi.org/10.1111/j.1432-1033.1967.tb00047.x

[26] McWilliam, H., Valentin, F., Goujon, M., Li, W., Narayanasamy, M., Martin, J., Miyar, T. and Lopez, R. (2009) Web Services at the European Bioinformatics Institute-2009. Nucleic Acids Research, 37, W6-W10.

[27] Whitmore, L. and Wallace, B.A. (2004) DICHROWEB, an Online Server for Protein Secondary Structure Analyses from Circular Dichroism Spectroscopic Data. Nucleic Acids Research, 32, W668-W673.

[28] Schirra, H.J., Scanlon, M.J., Lee, M.C., Anderson, M.A. and Craik, D.J. (2001) The Solution Structure of C1-T1, a Two-Domain Proteinase Inhibitor Derived from a Circular Precursor Protein from Nicotianaalata. Journal of Molecular Biology, 306, 69-79. http://dx.doi.org/10.1006/jmbi.2000.4318

[29] Lee, M.C., Scanlon, M.J., Craik, D.J. and Anderson, M.A. (1999) A Novel Two-Chain Proteinase Inhibitor Generated by Circularization of a Multidomain Precursor Protein. Nature Structural Biology, 6, 526-530. http://dx.doi.org/10.1038/9293

[30] Gonnelli, M., Balestreri, E., Romagnoli, A., Fissi, A., Cioni, P., Gabellieri, E. and Felicioli, R. (1986) Relationship of Disulfide Bonds to the Maintenance of the Active Secondary Structure of Alfalfa (Medicago sativa) Leaves Protease Inhibitor. Journal of Agricultural and Food Chemistry, 34, 545-547. http://dx.doi.org/10.1021/jf00069a044

[31] Crooks, G.E., Hon, G., Chandonia, J.-M. and Brenner, S.E. (2004) WebLogo: A Sequence Logo Generator. Genome Research, 14, 1188-1190. http://dx.doi.org/10.1101/gr.849004 


\section{Abbreviations}

BAEE: N- $(\alpha)$-benzoyl-L-arginine ethyl ester

BCA: Bicinconinic acid to determinated protein

BLAST: Basic local alignment search tool algorithm

CD: Circular dichroism

CID-MS: Collision-induced dissociation mass spectrometry,

$\mathrm{E}_{\mathrm{t}}$ : Total enzyme concentration

$I_{50}$ : Inhibitor concentration at which the velocity of the enzyme reaction was $50 \%$ of the uninhibited reaction

$\mathrm{K}_{\mathrm{i}}$ : Inhibition constant

$\mathrm{K}_{\mathrm{m}}$ : Michaelis constant

MALDI-TOF-MS: Matrix-assisted laser desorption/ionization time of flight mass spectrometry

MUSCLE: Multiple sequence comparison by Log-Expectation

PIJP: Protease inhibitor from jalapeño pepper (Capsicum annuum L.)

TFA: Trifluoroacetic acid

UA: Unit trypsin activity

UAI: Units trypsin activity inhibited 
Scientific Research Publishing (SCIRP) is one of the largest Open Access journal publishers. It is currently publishing more than 200 open access, online, peer-reviewed journals covering a wide range of academic disciplines. SCIRP serves the worldwide academic communities and contributes to the progress and application of science with its publication.

Other selected journals from SCIRP are listed as below. Submit your manuscript to us via either submit@scirp.org or Online Submission Portal.
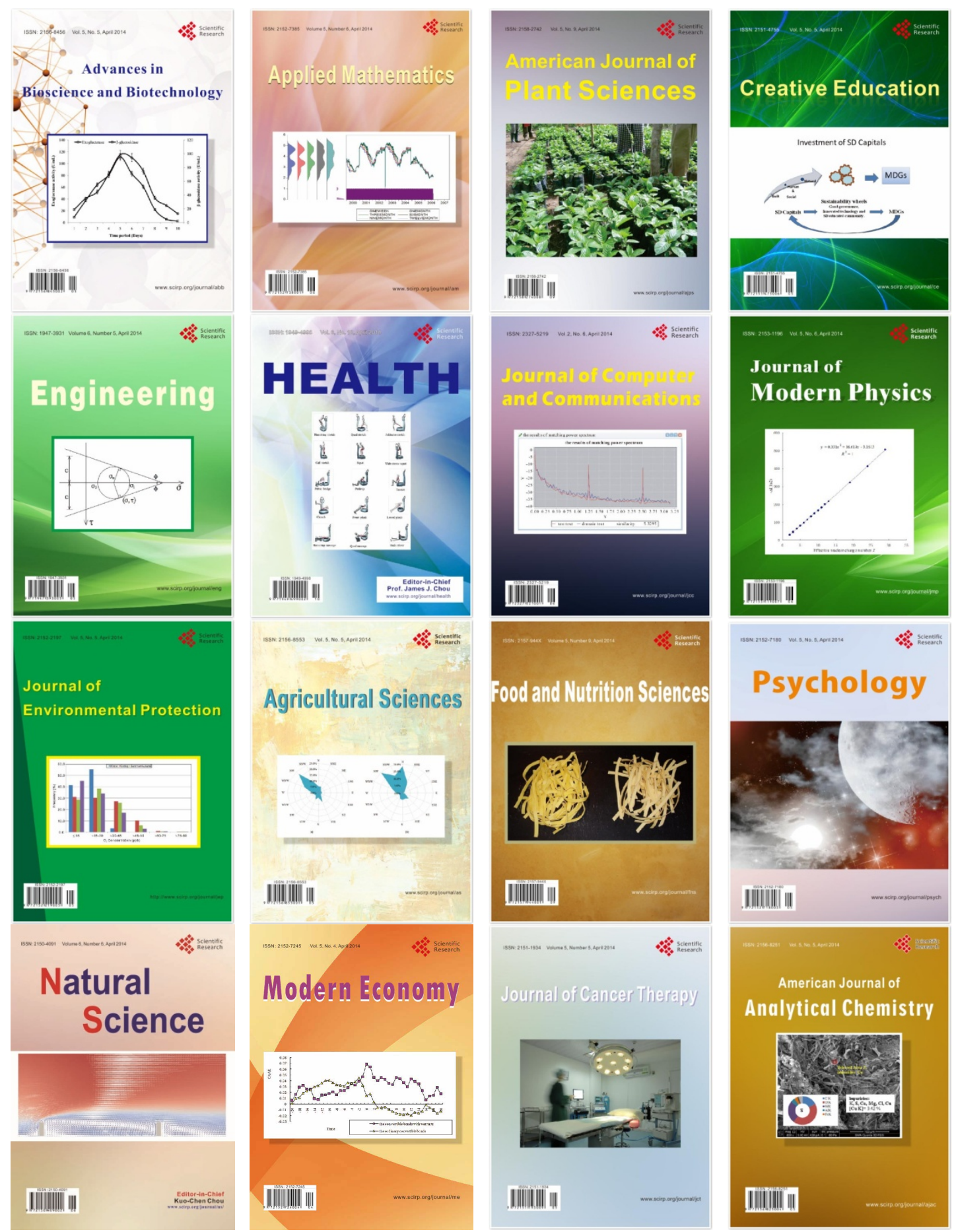